\title{
補償光学眼底カメラによる網膜中心動脈閉塞症の観察
}

\author{
後町 清子, 久保田大紀, 亀谷 修平 \\ 日本医科大学千葉北総病院眼科
}

\section{High-resolution Imaging of Central Retinal Artery Occlusion using Adaptive Optics Retinal Camera}

\author{
Kiyoko Gocho, Daiki Kubota and Shuhei Kameya \\ Department of Ophthalmology, Nippon Medical School Chiba Hokusoh Hospital
}

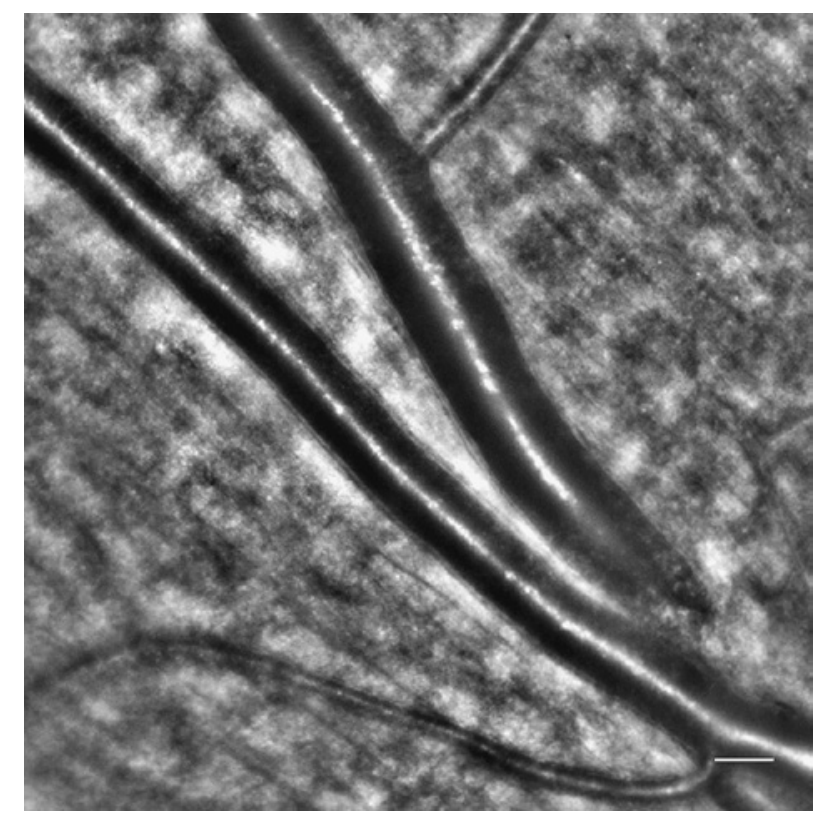

図 1

補償光学 Adaptive optics（AO） とは, 元来天文学分野 において発達した技術である. 大気中の摇らぎによって発 生する光の歪み，すなわち波面収差を補正し，より鮮明な 天体画像を得るために開発された。この技術を眼科的に応 用し, 眼底カメラに加えたものが補償光学眼底カメラであ る. 通常の眼底カメラの水平解像度は 15 から $20 \mu \mathrm{m}$ 程度 であるが, 補償光学眼底カメラは 2 から $4 \mu \mathrm{m}$ と詳細な生 体内網膜観察を可能にする。眼科分野では，AO 技術は眼 底カメラのみならず, 走査レーザー検眼鏡 $(\mathrm{SLO})$, 光干涉
断層計 $(\mathrm{OCT})$ にも用いられ，臨床あるいは研究目的に使 用されている.

$\mathrm{AO}$ 眼底カメラで最も研究が進んだ分野は錐体細胞の解 析であるが, 網膜の他の微細構造の観察も可能である ${ }^{11}$. 網 膜動脈の血管壁の厚さが測定できることから，高血圧など 全身疾患との関連についても研究報告がされている，血管 壁厚と血管径の比（wall to lumen ratio, WLR）と高血圧 症との相関があることが報告されている2).

連絡先：後町清子 $\bar{\top} 270-1694$ 千葉県印西市鎌苅 1715 日本医科大学千葉北総病院眼科

E-mail : kiyokog@nms.ac.jp

Journal Website (https://www2.nms.ac.jp/sh/jmanms/) 


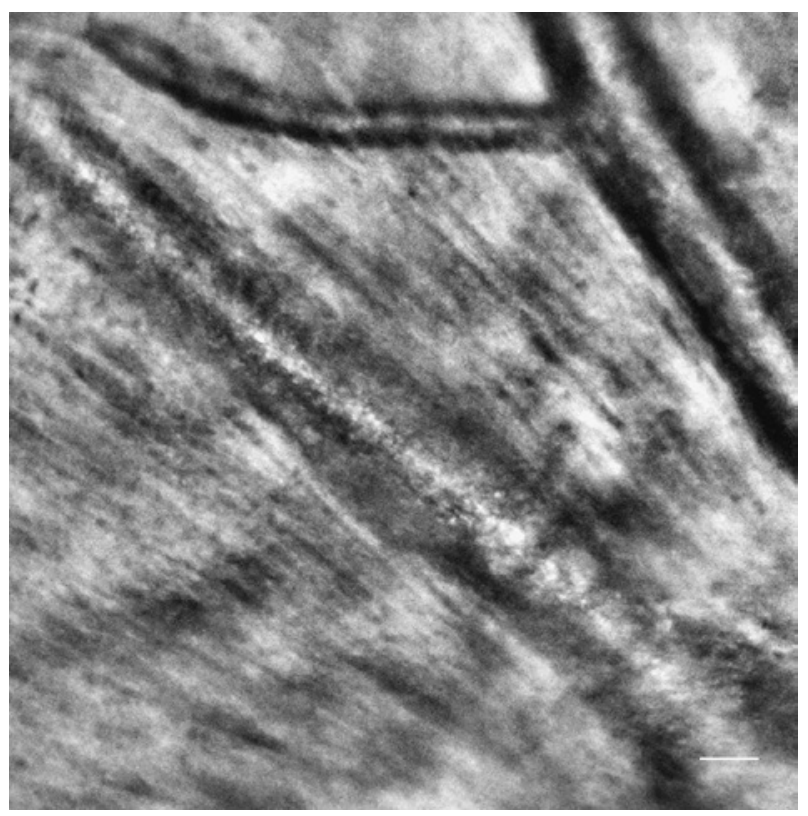

図 2

写真に健常者の網膜動静脈の写真（図 1）と網膜中心動 脈閉塞症を発症した症例（図 2) を示す。健常者では動脈 壁と血管内腔が明瞭に観察される。閉塞を起こした部分で は動脈壁の肥厚, 血管内腔の閉塞状態が観察される.

図 1 正常網膜動静脈. 29 歳女性（scale bar 100 micron）

\section{文 献}

1. Gocho K, Kikuchi S, Kabuto T, et al. "High-Resolution En Face Images of Microcystic Macular Edema in Patients with Autosomal Dominant Optic Atrophy." BioMed Research International 2013; 2013: 1-12.

2. Koch E, Rosenbaum D, Brolly A, et al. "Morphometric Analysis of Small Arteries in the Human Retina Using Adaptive Optics Imaging." Journal of Hypertension 2014; 32: 890-898.

3. Errera MH, Coisy S, Fardeau C, et al. "Retinal
他の糖尿病やぶどう膜炎など全身症状に伴う血管の変化 に対する観察の報告もあり ${ }^{3)}, \mathrm{AO}$ を用いたより詳細な生体 内微細構造の解明と臨床応用が期待されている.

図 2 網膜中心動脈閉塞症. 70 歳男性 (scale bar 100 micron)

Vasculitis Imaging by Adaptive Optics." Ophthalmology 2014; 121: 1311-1312. e2.

日本医科大学医学会雑誌は, 本論文に対して, クリエイティブ・ コモンズ表示 4.0 国際（CC BY NC ND）ライセンス（https:// creativecommons.org/licenses/by-nc-nd/4.0/) を採用した. ラ イセンス採用後も，すべての論文の著作権については，日本医 科大学医学会が保持するものとする. ライセンスが付与された 論文については，非営利目的の場合，元の論文のクレジットを 表示することを条件に，すべての者が，ダウンロード，二次使 用，複製，再印刷，頒布を行うことが出来る. 